\title{
Frequency, territorial distribution and antimicrobial resistance of Salmonella spp. on bovine cattle feces from the Altos Sur region of Jalisco State, Mexico
}

\author{
Frecuencia, distribución territorial y resistencia a los antimicrobianos de Salmonella spp. aislada de heces \\ de ganado bovino de la región Altos Sur en el estado de Jalisco, México
}

\begin{abstract}
Claudia Luz Navarro-Villarruel ', Luz María Ibarra-Velázquez , Joel David Diosdado-Rojas' , Ana Luisa Madriz-Elisondo', Marco Antonio Cardona-López ${ }^{1}$, Juan José Varela-Hernández¹ , Jesús Silva-Sánchez², Sofía María Arvizu-Medrano ${ }^{3}$ y J. Jesús Padilla-Frausto ${ }^{1 *}$

Centro Universitario de la Ciénega, Universidad de Guadalajara, Av. Universidad, No.1115, Col. Lindavista, Ocotlán, Jalisco, México, CP 47820.

2 Centro de Investigación sobre Enfermedades Infecciosas, Instituto Nacional de Salud Pública. Av. Universidad No. 655, Cerrada Los Pinos y Caminera, Col. Santa María Ahuacatitlán, Cuernavaca, Morelos, México, CP 62100.

3 Facultad de Química, Universidad Autónoma de Querétaro. Centro Universitario s/n, Col. las Campanas, Querétaro, Querétaro, México, CP 76010.
\end{abstract}

\section{ABSTRACT}

Multidrug resistance is a global public health problem. In 2017, in Mexico, Salmonella caused 192,771 foodborne zoonosis cases. Sonora, Hidalgo, Mexico State and Jalisco have reports of multi-resistant Salmonella strains in chicken and beef carcasses in slaughterhouses; however, the prevalence in livestock herds is unknown. From January 2012 to October 2013, 144 diarrheal stool samples were collected from bovine hatchlings from the Altos Sur region of the Jalisco State. As a result, the presence and serotype of Salmonella was determined, as well as the antibiotic resistance profile, and the genetic relationship, using PFGE. The Salmonella prevalence was $4.16 \%(6 / 144)$ in feces, identifying the serotypes Anatum, Pullorum, Poona, Typhi, Gallinarum and Salmonella enterica subsp. arizonae. All the strains showed resistance to ampicillin, cephalothin, trimethoprim-sulfamethoxazole, and some of them, additionally, to amikacin, cefotaxime and/or ceftriaxone. In addition, the persistence and potential spread of two Salmonella Anatum strains was discovered in one herd. This is the first study conducted in neonate bovine in the Jalisco State, Mexico, to detect multidrug resistant Salmonella. Continuous monitoring of multi-drug resistance in animal biota for human food and ongoing training of veterinary doctors are key elements for efficient prophylaxis and antimicrobial pharmacotherapy.

Key Words: Salmonella spp.; Multidrug-resistantance; Bovine cattle.

\section{RESUMEN}

La multifarmacorresistencia es un problema mundial de salud pública. En el 2017, en México, Salmonella causó 192,771 casos de zoonosis de origen alimentario. Sonora, Hidalgo, Estado de México y Jalisco tienen reportes de Salmonella multirresistente en canales de pollo y res en mataderos. Sin embargo, se desconoce la prevalencia en animales en hatos ganaderos. De enero-2012 a octubre-2013 se recolectaron 144 muestras de heces diarreicas de neonatos bovinos de la región Altos Sur del estado de Jalisco. Se determinaron los serotipos de Salmonella, el perfil de multifarmacorresistencia y el genotipo mediante PFGE. Se encontró una prevalencia del $4.16 \%(6 / 144)$ de Salmonella en heces, recuperándose los serotipos Anatum, Pullorum, Poona, Typhi, Gallinarum y Salmonella enterica subsp. arizonae. Todas las cepas mostraron resistencia a ampicilina, cefalotina, trimetoprim-sulfametoxazol y adicionalmente algunas a amikacina, cefotaxima y/o ceftriaxona. Se descubrió una persistencia y propagación de dos cepas de Salmonella Anatum en un hato. Este es el primer estudio realizado en bovinos recién nacidos en el estado de Jalisco, México, para la detección de Salmonella multirresistente. Es necesario el monitoreo continuo de la multi-farmacorresistencia en la biota de animales para alimento humano y una capacitación continua de médicos veterinarios para una eficiente profilaxis y farmacoterapia antimicrobiana.

Palabras claves: Salmonella spp.; Multifarmacorresistencia; Ganado bovino.

\section{INTRODUCTION}

World beef production grew annually at an average rate of 0.6 percent during the recent decade, reaching a record high of 62.48 million tons of carcass meat in 2018 (United States Department of Agriculture; USDA, 2019). Mexico ranked as the eighth meat producer, with 3.2 percent of the total production (USDA, 2019). In Mexico, the Ministry of Agriculture and Rural Development, through the Agri-Food and Fisheries Information Service, reported a steady growth in beef production over the past decade, at an average annual rate of 1.7 percent, reaching a historical maximum of 1.98 million tons of carcass meat in 2018. Estimates indicate that in 2019 national production increased 2.4 percent, with what could be 2.03 million tons, while projections suggest that in 2020 it will only grow 1.9 percent (USDA, 2019). The 
national consumption of bovine meat decreased at an annual average rate of 0.8 percent in the last decade, reaching 1.87 million tons in 2018. In 2019 this increase hit 2.02 million tons, which means the tendency is growing at an annual average rate of 0.43 percent, and it will reach 0.5 percent in 2020 (COMECARNE, 2019). Per capita consumption of beef in Mexico increased between 2015 and 2019, from 15.2 to 15.4 kilograms per year. Since 2015, Mexico recorded a surplus balance in the beef trade balance, which historically had been in deficit. In 2019, net exports of 273.5 thousand tons of beef were reported, the highest volume in the last five years, with an annual increase of 36.9 percent (COMECARNE, 2017; SADER, 2019; COMECARNE, 2019). According to USDA Foreign Agricultural Trade of the United States table, the surplus balance in the trade balance could increase 32.6 percent in 2021 (FATUS-USDA, 2020). The most purchased cuts are steak and milanese, followed by pulp, piece and ground meat (COMECARNE, 2019). Jalisco state is the second largest producer of bovine meat in Mexico, with $13.2 \%$ of the 1,915 million tons of national production in 2019, and this amount represents the mobilization and slaughtering of approximately 280 thousand heads of cattle (SADER, 2019). The Jalisco regional livestock union, in its 2019 annual report noted that the northeast area of the state, which includes the Altos Norte and Altos Sur regions, participates with $46.4 \%$ of the state livestock production (UGRJ, 2019). Livestock production in the Altos Sur region maintained an increasing trend during the 2013-2018 period, with 2018 being the year with the highest growth in the value of livestock production in the region, representing $34.4 \%$ of the entire state production (IIEG, 2019). Among the livestock products for whose production the Altos del Sur region stands out, the egg is in first place with $47.4 \%$ of the total value of the region's production, followed by pork meat with $19.4 \%$, bovine milk with $17.2 \%$, bovine carcass meat with $11.3 \%$ and poultry meat with $4.6 \%$ (IIEG, 2019). In the region, from 2013 to 2019, the number of cattle herds producing beef cattle rose from 106 to 159 (IIEG, 2019).

Salmonella is the most important foodborne pathogenic bacteria worldwide. In Mexico, Salmonella is the most commonly reported bacterial pathogen in gastrointestinal infections, with 192,771 salmonellosis cases reported in 2019 to the National Center for Epidemiological Surveillance and Control of Diseases (Secretaría de Salud, 2017). Food producing animals are the main reservoir of non-typhoidal Salmonella (Elder et al., 2000; Callaway et al., 2008). These pathogens can originate from the animal's intestinal contents and hides in carcasses during harvesting and dressing process (Barkocy-Gallagher et al., 2003).

The emergence of multidrug-resistant (MDR) Salmonella isolates among animals and humans has been documented, and represents a public health concern (Arthur et al., 2008). Some reports have indicated that the use of antimicrobials in animal production for disease therapy, prophylaxis, and growth enhancement promotes the selection of resistant bacteria, although the impact of these uses on human health is not clearly understood yet (Mathew et al.,
2007; WHO, 2008). Resistance of pathogenic bacteria to antimicrobials used in human therapy may result in lower efficacy of these drugs against infections and may subsequently threaten public health (Geornaras et al., 2012).

Guidelines for prudent use of antimicrobial agents may help to slow down the selection for resistance, and should be based on knowledge regarding the normal susceptibility patterns of the causative agents and consider the potential human health problems (Aarestrup, 2005). According to the World Health Organization (WHO, 2008), surveillance programs are needed to monitor the antimicrobial prevalence and resistance of Salmonella isolates from animals, humans, and food (Aidara-Kane et al., 2018).

In Mexico, there are no surveillance reports of Salmonella strains with antimicrobial resistance in newborn cattle. It is necessary to generate monitoring programs for MDR Salmonella presence in the main livestock areas. These programs can be useful to develop public health policies for the regulation of drugs used in food-producing animals and to design control measures to prevent the spread of MDR bacteria (Whichard et al., 2010). The purpose of this study was to determine the frequency, territorial distribution and antimicrobial resistance of Salmonella on cattle feces from the Altos Sur region of Jalisco State, Mexico.

\section{MATERIALS AND METHODS Design of the investigation}

This is a descriptive cross-sectional study to determine the frequency, territorial distribution and antimicrobial resistance of Salmonella spp., on bovine cattle feces from the Altos Sur region in the Jalisco State, Mexico, during the period from January-2012 to October-2013.

\section{Sample collection}

A total of 144 diarrheal feces samples were collected from cattle from fourteen different herds, located in eleven of the twelve municipalities in the Altos Sur region of Jalisco State, Mexico, during a 21-month period (January-2012 to October-2013), on the condition that the cattle did not exceed four months of age. Samples were collected from at least one herd of cattle in each of the municipalities of the region; unfortunately, it was not possible to collect a sample from San Ignacio Cerro Gordo. Five grams of cattle diarrheal feces were collected in sterile bags (Speci-Sponge, Nasco Whirl-Pak, Modesto, CA) with $20 \mathrm{~mL}$ of buffered peptone water (BD, Franklin Lakes, $\mathrm{NJ}$ ), thus fulfilling the procedure described by the U.S. Department of Agriculture Food Safety and Inspection Service (USDA-FSIS, 1996).

\section{Salmonella isolation}

Each sample was added to $40 \mathrm{~mL}$ of buffered peptone water for a total volume of $60 \mathrm{~mL}$, homogenized for $2 \mathrm{~min}$ with a bag mixer (Stomacher ${ }^{\circledast} 80$ Biomaster), and incubated at $35^{\circ} \mathrm{C}$ for 18 to $22 \mathrm{~h}$. After incubation, 1.0 and $0.1 \mathrm{~mL}$ aliquots were inoculated into 9 and $9.9 \mathrm{~mL}$ of tetrathionate broth (BD) and Rapapport-Vassiliadis broth (BD), respectively. 
Both selective enrichment broths were incubated at $42^{\circ} \mathrm{C}$ for $16 \mathrm{~h}$. After incubation, $1.0 \mathrm{~mL}$ aliquots of each enrichment broth were individually transferred to tubes containing 10 $\mathrm{mL}$ of $\mathrm{M}$ broth (BD) and incubated at $35^{\circ} \mathrm{C}$ for 6 to $8 \mathrm{~h}$. After incubation, $0.5 \mathrm{~mL}$ aliquots of $\mathrm{M}$ broth culture from each tube were combined for an enzyme-linked immunosorbent assay (Salmonella VIA, TECRA International) (Hughes et al., 2003) according to the manufacturer's instructions. Aliquots from tetrathionate and Rapapport-Vassiliadis cultures from samples that were positive for Salmonella with the enzymelinked immunosorbent assay were individually streaked onto brilliant green sulfa agar (BD), bismuth sulfite agar (Bioxon), and xylose lysine Tergitol 4 agar (BD). All plates were incubated at $35{ }^{\circ} \mathrm{C}$ for 24 to $48 \mathrm{~h}$. From each selective agar type, we selected and streaked at least three colonies with characteristics typical for Salmonella, onto triple sugar iron agar (BD) and lysine iron agar (BD) and incubated at $35^{\circ} \mathrm{C}$ for $24 \mathrm{~h}$. Isolates with typical biochemical reactions were then streaked onto Tryptic Soy agar (TSA; BD), incubated at $35^{\circ} \mathrm{C}$ for $24 \mathrm{~h}$, and tested for slide agglutination using polyvalent serum A-Vi (BD). Isolates that produced nontypical triple sugar iron agar and lysine iron agar reactions, and/or negative serological reactions, were tested for additional biochemical analysis in Methyl Red-Voges Proskauer medium, Simmons Citrate agar, Urease Rustigian and Stuart broth, motility medium, and Phenol Red Salicin and Dulcitol Fermentation broths (Bioxon) (USDA-FSIS, 2008). One isolate from each positive sample was randomly chosen for serotyping and antimicrobial susceptibility testing.

\section{Serotyping}

Salmonella cultures were reactivated in TSB at $35^{\circ} \mathrm{C}$ for $24 \mathrm{~h}$ and then individually streaked on Brilliant Green Sulfa agar (BD) plates. From each culture, one colony with typical Salmonella characteristics was individually inoculated on TSA slants, incubated at $35{ }^{\circ} \mathrm{C}$ for $24 \mathrm{~h}$, reconfirmed by biochemical and serological testing as previously described, and then shipped to the Institute of Epidemiological Diagnosis and Reference "Dr. Manuel Martínez Báez" (InDRE, Mexico City, Mexico) for serotype identification, according to the Kauffman-White scheme (1974).

\section{Pulsed-field gel electrophoresis (PFGE) for subtyping of Salmonella serotypes}

Individual bacterial colonies of Salmonella strains, grown over $24 \mathrm{~h}$ at $37{ }^{\circ} \mathrm{C}$ on Trypticase Soy Agar (BD) plates were directly suspended using cotton swabs in $3 \mathrm{~mL}$ of TE buffer (100 mM Tris and $100 \mathrm{mM}$ EDTA, pH 8.0). Cell suspensions were adjusted with TE buffer to 0.700 absorbance using a Varian Cary 50 Scan UV-visible spectrophotometer. Cell suspension aliquots $(400 \mu \mathrm{L})$ were transferred to $1.5 \mathrm{~mL}$ microcentrifuge tubes. Lysozyme (10 $\mathrm{mg} / \mathrm{mL}$ stock solution) and proteinase $\mathrm{K}(20 \mathrm{mg} / \mathrm{mL}$ stock solution) were added at a final concentration of $1 \mathrm{mg} / \mathrm{mL}$ each, and mixed several times by pipetting up and down. The bacterial suspensions were incubated at $37^{\circ} \mathrm{C}$ for $15 \mathrm{~min}$. UltraPure ${ }^{\mathrm{TM}}$ Agarose gel
(Invitrogen) was prepared in $0.5 \mathrm{X}$ TBE to a final concentration of $1 \%$ and maintained at $55{ }^{\circ} \mathrm{C}$ in a water bath. Following the lysozyme-proteinase $\mathrm{K}$ incubation, $7 \mu \mathrm{L}$ of $20 \%$ sodium dodecyl sulfate and $140 \mu \mathrm{L}$ of $1 \%$ UltraPure $^{\mathrm{TM}}$ Agarose gel (Invitrogen) were mixed with each bacterial suspension with the help of a pipette. This bacterium-agarose mixture was immediately added to plug molds (Bio-Rad Laboratories). The plugs were allowed to solidify for $10 \mathrm{~min}$ at $4{ }^{\circ} \mathrm{C}$, then transferred to $2 \mathrm{~mL}$ round-bottom tubes containing $1.5 \mathrm{~mL}$ of TESP buffer ( $50 \mathrm{mM}$ Tris, $50 \mathrm{mM}$ EDTA, pH 9.0; 1 \% sodium lauryl sarcosine; $1 \mathrm{mg}$ of proteinase $\mathrm{K}$ per $\mathrm{mL}$ ), and incubated with gentle mixing in a shaker water bath at $55^{\circ} \mathrm{C}$ for $2 \mathrm{~h}$. After the completion of proteolysis, the plugs were transferred to $1.5 \mathrm{~mL}$ microcentrifuge tubes containing $200 \mu \mathrm{L}$ of sterile, preheated $\left(50^{\circ} \mathrm{C}\right)$ distilled water and incubated for $10 \mathrm{~min}$ at $50{ }^{\circ} \mathrm{C}$ with gentle mixing in a shaker water bath. Subsequently, four $50^{\circ} \mathrm{C}$ washes were done in a shaker water bath for 15 min each with $400 \mu \mathrm{L}$ of preheated $\left(50^{\circ} \mathrm{C}\right)$ TE buffer (10 mM Tris, pH 8.0; 1 mM EDTA, pH 8.0), and plugs cooled to room temperature in TE buffer. For restriction endonuclease digestion, two $1 \mathrm{~mm}$ thick slices of each plug were incubated at $37^{\circ} \mathrm{C}$ for $3 \mathrm{~h}$ with $3 \mu \mathrm{L}$ of $\mathrm{Xbal}$ (Invitrogen), in $100 \mu \mathrm{L}$ of the restriction enzyme buffer (containing $4 \mu \mathrm{L}$ of restriction enzyme buffer (10x), $0.1 \%$ BSA and $29 \mu \mathrm{L}$ of sterile DNase/ RNase-Free Distilled Water) as recommended by the manufacturer.

The plug slices of the samples were loaded and electrophoresed in $1 \%$ UltraPure ${ }^{\mathrm{TM}}$ agarose (Invitrogen) with 2 liters of standard 0.5X TBE running buffer. Electrophoresis of the prepared samples was performed on the CHEF-DR III system (Bio-Rad). The electrophoretic conditions used were as follows: initial switch time, $2.16 \mathrm{~s}$; final switch time, $55 \mathrm{~s}$; run time, $22 \mathrm{~h}$; angle, $120^{\circ}$; gradient, $6.0 \mathrm{~V} / \mathrm{cm}$; temperature, $14{ }^{\circ} \mathrm{C}$; ramping factor, linear. After electrophoresis, the gels were stained for $30 \mathrm{~min}$ in 1 liter of sterile distilled water containing $50 \mathrm{~mL}$ of ethidium bromide $(10 \mathrm{mg} / \mathrm{mL})$ and destained with three 1 -liter distilled water washes ( 30 min each); then, photographed under UV illumination with Kodak film (Edas 290) in 8-bit negative format in gray scale. Additional analysis and construction of dendrograms and trees were done with GelCompar Il software (version 2.0; Applied Maths, Sint-Martens-Latem, Belgium). The molecular size marker (Xbal-digested DNA from S. enterica serotype Braenderup H9812) was included in all runs as a control. The consistency of the control DNA patterns confirmed the reproducibility of the procedure.

\section{Antimicrobial susceptibility testing}

Antimicrobial susceptibility was determined according to the disk diffusion method on Mueller-Hinton agar as described by the Clinical and Laboratory Standards Institute (CLSI, 2009; CLSI, 2010). Antimicrobial susceptibility test disks (BBL, BD, Sparks, MD) were used for the following antimicrobials of veterinary and human health importance: ampicillin (AMP, $10 \mu \mathrm{g})$, gentamicin (GEN, $10 \mu \mathrm{g})$, amikacin (AN, $30 \mu \mathrm{g})$, trimethoprim-sulfamethoxazole (SXT, 1.25 and $23.75 \mu \mathrm{g}$ ), ceftriaxone $(C R O, 30 \mu \mathrm{g})$, cefotaxime $(C T X, 30 \mu \mathrm{g})$, polymyxin 
$\mathrm{B}$ (PB, 300 units) and cephalothin (CEP, $30 \mu \mathrm{g})$. Escherichia coli ATCC 25922 was used as a quality control. Inhibition zones were measured as MIC breakpoints according to the M100S20, (CLSI, 2010). Multidrug resistance was reported when resistance to three or more antimicrobials was observed (Miranda et al., 2009). It is worth mentioning that the antibiotics selection was made according to the therapeutic recommendation against suspected gastrointestinal diseases caused by resistant and non-resistant Salmonella (CDC, 2009).

\section{Complementary study}

Additionally, in October 2013 and January 2017, a survey was conducted to evaluate the sale frequency of the different groups of antibiotics in veterinary pharmacies of the region, with the aim of explaining the possible resistance of isolated Salmonella strains. Thirty-six veterinary pharmacies were included in this study. The number of sold vials of each antibiotics group in the last two months was recorded, as an indicator of the pharmacological preferences of the region's veterinary doctors or livestock farmers.

\section{Data analysis}

The differences significance $(p \leq 0.05)$ in Salmonella isolation frequency by cattle farm were evaluated with the Kruskal-Wallis test and the Fisher's LSD test and the preference for the best-selling antimicrobials in the region's veterinary pharmacies were evaluated with the chi-square test in the Statistical Package for Social Science, version 11.5 for Windows (SPSS, Chicago, IL).

\section{RESULTS}

Table 1. Frequency of Salmonella serotypes in cattle feces from the Altos Sur region in Jalisco State, Mexico (Jan-2012 to Oct-2013).

Tabla 1. Frecuencia de los serotipos de Salmonella en heces de ganado de la región de Altos Sur en el estado de Jalisco, México (ene-2012 a oct-2013).

\begin{tabular}{|c|c|c|c|c|}
\hline Municipalities & $\begin{array}{l}\text { Cattle } \\
\text { herd }\end{array}$ & $\begin{array}{l}\text { No. of stool } \\
\text { samples of } \\
\text { cattle feces } \\
\text { per herd }\end{array}$ & $\begin{array}{l}\text { No. of Salmonella spp. positive samples } \\
\text { (Percentage with respect to the total } \\
\text { samples analyzed per herd,\%) }{ }^{1} \text { /No. of } \\
\text { strains isolated }\end{array}$ & $\begin{array}{c}\text { Salmonella } \\
\text { serotype isolate and } \\
\text { another subsp. (No. of } \\
\text { strains isolated) }\end{array}$ \\
\hline \multirow[t]{2}{*}{ Mexticacán } & A & 13 & $2(\mathbf{1 5 . 3 8})^{\mathrm{b}} / 2$ & $\begin{array}{c}\text { Pullorum(1) } \\
\text { Salmonella enterica subsp. } \\
\text { arizonae( } 1 \text { ) }\end{array}$ \\
\hline & B & 9 & $0^{c}$ & - \\
\hline San Julián & C & 3 & $0^{c}$ & - \\
\hline Capilla de Guadalupe & D & 4 & $0^{c}$ & - \\
\hline Jesús María & E & 13 & $0^{c}$ & - \\
\hline Valle de Guadalupe & $\mathrm{F}$ & 6 & $0^{c}$ & - \\
\hline Jalostotitlán & G & 7 & $0^{c}$ & - \\
\hline San Miguel El Alto & $\mathrm{H}$ & 16 & $0^{c}$ & - \\
\hline \multirow[t]{2}{*}{ Tepatitlán de Morelos } & 1 & 24 & $0^{c}$ & - \\
\hline & J & 10 & $1(\mathbf{1 0 . 0 0})^{b} / 1$ & Gallinarum(1) \\
\hline Yahualica de González Gallo & $\mathrm{K}$ & 14 & $2(\mathbf{1 4 . 2 9})^{b} / 3$ & $\begin{array}{l}\text { Anatum(2) } \\
\text { Typhi(1) }\end{array}$ \\
\hline \multirow[t]{2}{*}{ Arandas } & $\mathrm{L}$ & 18 & $0^{c}$ & - \\
\hline & M & 6 & $0^{c}$ & - \\
\hline Cañadas de Obregón & $\mathrm{N}$ & 1 & $1(\mathbf{1 0 0})^{a} / 1$ & Poona(1) \\
\hline Total & & 144 & $6(4.16) / 7$ & \\
\hline
\end{tabular}

${ }^{1}$ Within these columns, values with different letters are significantly different $(p \leq 0.05)$ by Kruskal-Wallis test and Fisher's LSD test. 

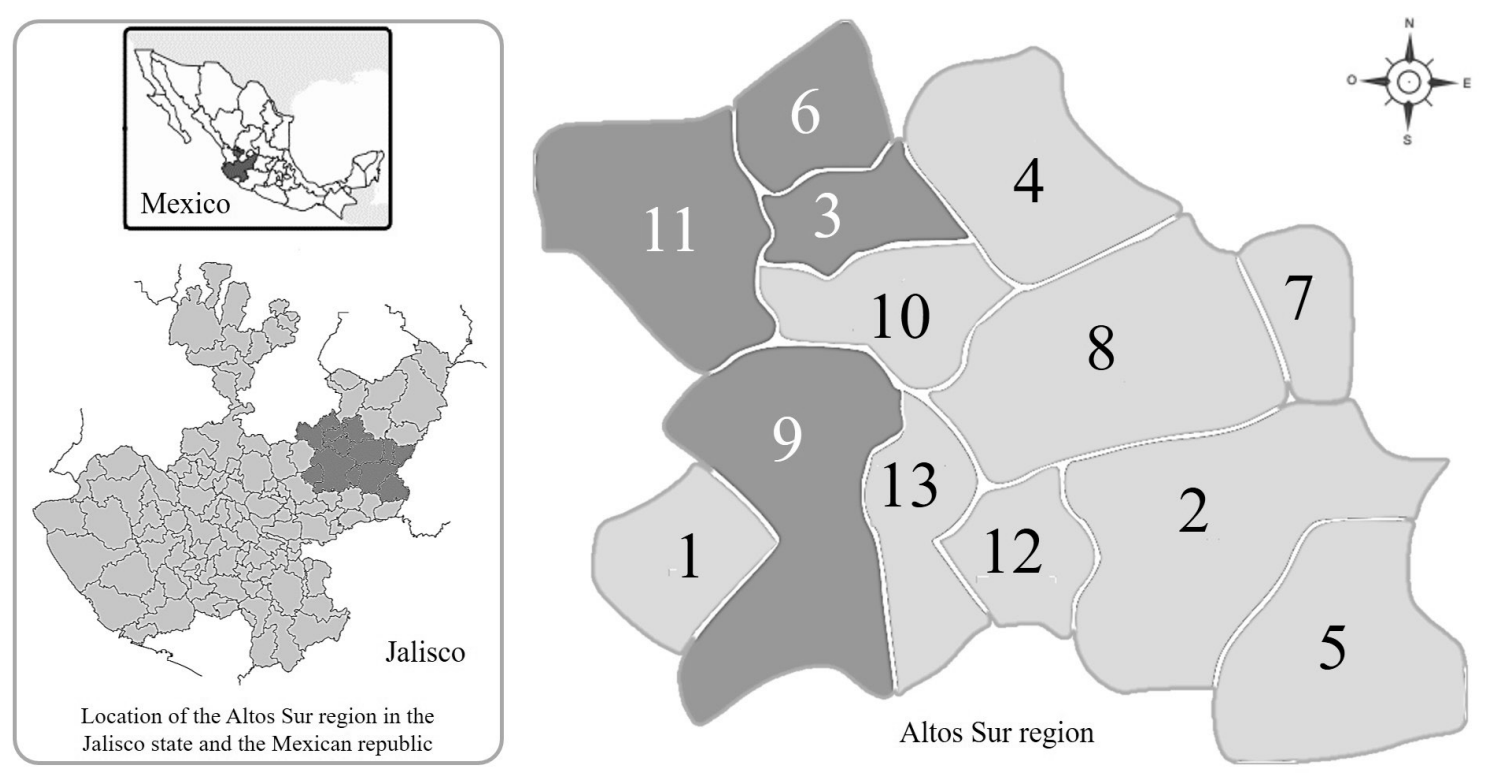

Figure 1. Territorial distribution of samples positive for Salmonella in the Altos Sur region in Jalisco. 1. Acatic, 2. Arandas, 3. Cañadas de Obregón, 4. Jalostotitlán, 5. Jesús María, 6. Mexticacán, 7. San Julián, 8. San Miguel el Alto, 9. Tepatitlán de Morelos, 10. Valle de Guadalupe, 11. Yahualica de González Gallo and 12. San Ignacio Cerro Gordo (not included in the study).

Figura 1. Distribución territorial de las muestras positivas para Salmonella, en los Altos Sur de Jalisco. 1. Acatic, 2. Arandas, 3. Cañadas de Obregón, 4. Jalostotitlán, 5. Jesús María, 6. Mexticacán, 7. San Julián, 8. San Miguel el Alto, 9. Tepatitlán de Morelos, 10. Valle de Guadalupe, 11. Yahualica de González Gallo y 12. San Ignacio Cerro Gordo (municipio no incluido en este estudio).

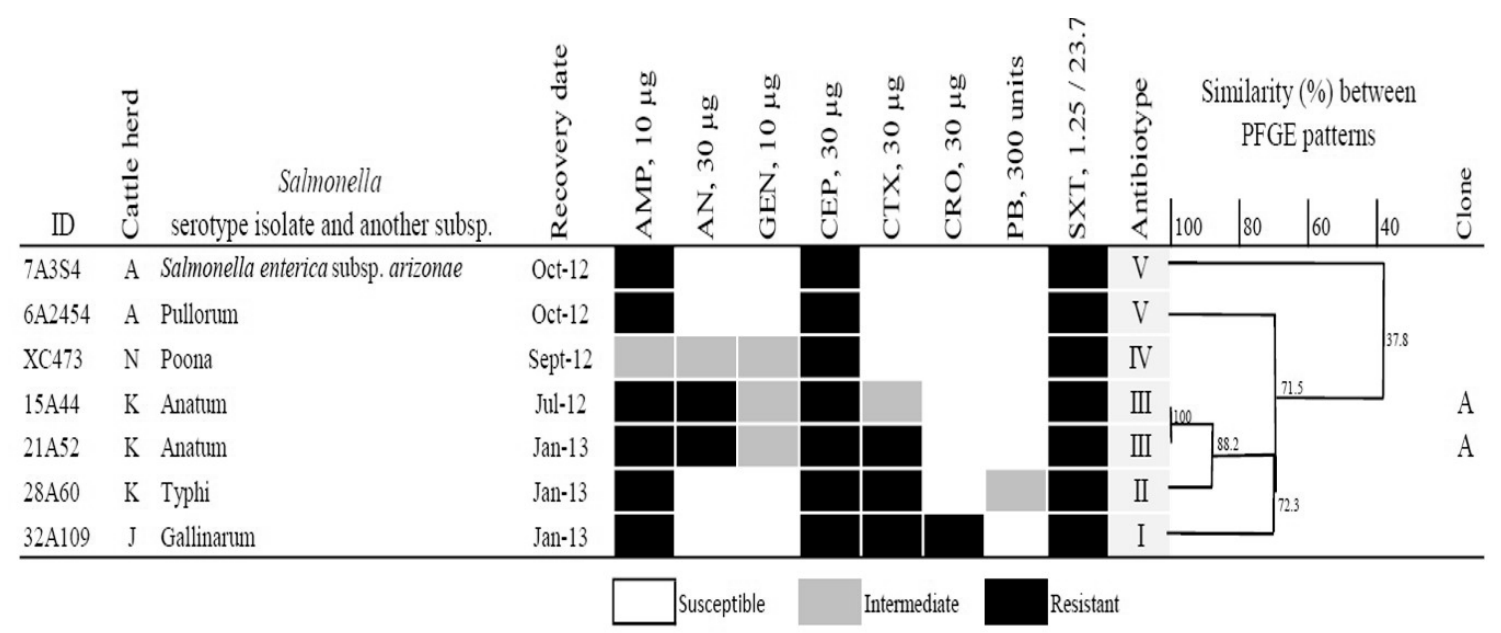

Figure 2. Antimicrobial susceptibility patterns and PFGE of Salmonella serotypes. AMP: Ampicillin, AN: Amikacin, GEN: Gentamicin, CEP: Cephalothin, CTX: Cefotaxime, CRO: Ceftriazone, PB: Polymyxin B and, SXT: Trimethoprim-Sulfamethoxazole. Figura 2. Patrones susceptibilidad a antimicrobianos y PFGE de los serotipos de Salmonella. AMP: Ampicilina, AN: Amikacina, GEN: Gentamicina, CEP: Cefalotina, CTX: Cefotaxima, CRO: Ceftriazona, PB: Polimixina B y, SXT: Trimetoprim-Sulfametoxazol.

Based on observations, the most requested chemical groups in veterinary pharmacies are aminopenicillins, sulfonamides (with and without dihydrofolate reductase inhibitors), penicillins, cephalosporins and first, third and fourth-generation fluoroquinolones. The 2014 results were reported to the Commission for the Protection against Sanitary Risks of the State of Jalisco (COPRISJAL), which in 2015, with the support of the College of Veterinary Doctors of the State of Jalisco (Civil Association), started an awareness and training campaign on the public health impact of multi-drug resistant pathogens, the use of antibiotics in livestock feed and antimicrobial therapeutic alternatives for farm cattle. In early 2017, the veterinary pharmacies survey in the Altos Sur region of Jalisco was repeated to observe changes in the trend of the veterinary doctors' preferences for the different antimicrobial drugs. The results of the survey indicate that the demand for aminopenicillins and sulfonamides (with and without dihydrofolate reductase inhibitors) has increased. These are the antimicrobial drugs recommended by the FDA National Antimicrobial Resistance Monitoring System (NARMS, 2010) 
Table 2. Changes in the antimicrobials dispensing preference in veterinary pharmacies at the Altos Sur region of Jalisco State, Mexico.

Tabla 2. Cambios en la preferencia de dispensación de antimicrobianos en farmacias veterinarias en la región de Altos Sur del estado de Jalisco, México.

\begin{tabular}{|c|c|c|c|c|}
\hline \multirow[t]{2}{*}{ Class of drugs } & \multirow[t]{2}{*}{ Antibiotics } & \multicolumn{2}{|c|}{$\begin{array}{c}\text { Number of veterinary } \\
\text { pharmacies' (Relative } \\
\text { frequency) }\end{array}$} & \multirow[t]{2}{*}{$\begin{array}{c}\text { Change in acquisition } \\
\text { preference }\end{array}$} \\
\hline & & October 2013 & January 2017 & \\
\hline Aminoglycoside & Amikacin ${ }^{b}$ & $2(5.6 \%)$ & $2(5.6 \%)$ & Without changes \\
\hline Aminoglycoside & Gentamicin ${ }^{b}$ & $3(8.3 \%)$ & $3(8.3 \%)$ & Without changes \\
\hline Aminopenicillins & Ampicillin ${ }^{a}$ & $15(41.7 \%)$ & $18(50.0 \%)$ & Increase \\
\hline Beta-lactam & Penicillin G a & $8(22.2 \%)$ & $7(19.4 \%)$ & Reduction \\
\hline Beta-lactam & Oxacillin ${ }^{a}$ & $1(2.8 \%)$ & $0(0 \%)$ & Reduction \\
\hline Beta-lactam/beta-lactamase inhibitors & Amoxicillin with clavulanic acid ${ }^{a}$ & $5(13.9 \%)$ & $8(22.2 \%)$ & Increase \\
\hline Cephalosporin (First-generation) & Cephalothin ${ }^{a, b, d}$ & $8(22.2 \%)$ & $5(13.9 \%)$ & Reduction \\
\hline Cephalosporin (Third-generation) & Ceftriaxone ${ }^{a, b, d}$ & $7(19.4 \%)$ & $5(13.9 \%)$ & Reduction \\
\hline Cephalosporin (Third-generation) & Cefotaxime $^{a, b, d}$ & $4(11.1 \%)$ & $1(2.8 \%)$ & Reduction \\
\hline Cephalosporin (Fourth-generation aminothiazolyl) & Cefquinome eff,g & $2(5.6 \%)$ & $3(8.3 \%)$ & Increase \\
\hline Cephalosporin (Fourth-generation) & Cefepime ${ }^{a, b, d}$ & $9(25.0 \%)$ & $4(11.1 \%)$ & Reduction \\
\hline Cyclic non-ribosomal polypeptide & Polymyxin $B^{b}$ & $2(5.6 \%)$ & $1(2.8 \%)$ & Reduction \\
\hline Fluoroquinolone & Ciprofloxacin e & $1(2.8 \%)$ & $1(2.8 \%)$ & Without changes \\
\hline Fluoroquinolone & Danofloxacin e & $7(19.4 \%)$ & $9(25.0 \%)$ & Increase \\
\hline Sulfonamide & Sulfadiazine ${ }^{a, e}$ & $14(38.9 \%)$ & $19(52.8 \%)$ & Increase \\
\hline Sulfonamide/inhibitor of dihydrofolate reductase & Trimethoprim-Sulfamethoxazole a,be,f & $17(47.2 \%)$ & $18(50.0 \%)$ & Increase \\
\hline Tetracycline & Oxytetracycline $^{c}$ & $1(2.8 \%)$ & $1(2.8 \%)$ & Without changes \\
\hline Tetracycline & Minocycline $^{b}$ & $2(5.6 \%)$ & $0(0 \%)$ & Reduction \\
\hline Tetracycline & Doxycycline $^{b}$ & $0(0 \%)$ & $3(8.3 \%)$ & Increase \\
\hline
\end{tabular}

${ }^{1}$ Number of veterinary pharmacies that reported it as one of the three best-selling antibiotics of 36 veterinary outlets surveyed. ${ }^{2}$ (No. of veterinary pharmacies that reported it as one of the three best-selling antibiotics/36 veterinary outlets surveyed) $x 100 .{ }^{3}$ Changes with statistical significance $(p \leq 0.05)$.

aFor wounds treatment

${ }^{\mathrm{b}}$ For gastrointestinal infections treatment

In livestock feed to prevent diseases and infections in cattle

ds contraindicated in neonates cattle

eFor respiratory disease treatment

${ }^{f}$ For mastitis treatment in dairy cattle

IIt is only used in veterinary applications

for veterinary use in wounds, mastitis, gastrointestinal and respiratory infection treatments. In contrast, there was a reduction in the demand of first and third-generation cephalosporins, while the consumption of cefquinome raised, which is a fourth-generation cephalosporin recommended exclusively for veterinary use.

\section{DISCUSSION}

As an infectious, contagious pathogen, Salmonella is probably rivaled just by bovine viral diarrhea virus in its ability to cause clinical diseases, such as enteritis, septicemia, pneumonia, and reproductive losses (Holschbach and Peek, 2018). The increasing prevalence of Salmonella presents new challenges to meat producers and veterinarians. No current discussion on bovine salmonellosis is complete without acknowledging the increasing public health concern. Increasing antimicrobial resistance among enteric pathogens brings the use of antimicrobials by veterinarians and producers under an increasingly strict scrutiny. There are no studies in Mexico on this pathogen prevalence in newborn cattle. However, the presence of the pathogen can be assumed as a commensal biota in their intestine, which will accompany them during their life to the slaughterhouse. Hence, it can be also assumed that the contamination of the carcass can be configured, if hygienic practices are not maintained in the gutted during the slaughter. In this respect, there are studies on the prevalence of this pathogen in slaughterhouse meat that report the contamination of the carcass.

In Mexico, Narvaez et al., (2013) and Pérez-Montano et al., (2012) reported information related to the presence of Salmonella on beef carcasses in abattoirs and cattle feedlots, indicating a Salmonella presence of $5.2 \%$ and $55.56 \%$, respectively. They also reported that all abattoirs included in her study had failed to comply with good manufacturing practices (GMPs) and sanitation standard operating procedures (SSOPs), and none had implemented a food safety system. Fecal contamination on beef carcasses was visible and cross-contamination was common during operations 
at all abattoirs. Without excluding GMPs and SSOPs during rearing, dressing and slaughter, it is important to evaluate and control the presence of Salmonella and other pathogens in farm cattle at the different stages of their life (neonate, reproductive age and prior to slaughter). In addition to this, Barkocy-Gallagher et al. (2003) reported that Salmonella prevalence on pre-eviscerated beef carcasses was higher during summer and fall (19.7 to $24.9 \%$ ) than in winter and spring (3.0 to $4.1 \%$ ). During the wet season, cattle hides are more likely to be soiled with mud and feces, increasing the possibility of carcass contamination during hide removal and evisceration (Rivera-Betancourt et al., 2004). It is worth mentioning that the mere presence of the pathogen in the intestine of the animal of origin and, unfortunately, in its carcass, does not necessarily have an impact on the consumer's disease, cross contamination with other raw or cooked foods must occur and/or an inadequate thermal elimination of the pathogen in the food of meat origin. However, all the Salmonella serotypes and Salmonella enterica subsp. arizonae that were isolated in this study have been previously related, as ethological agents, to disease outbreaks due to poorly cooked meats intake (Geimba et al., 2004; Gould et al., 2004; Duggan et al., 2012; Evangelopoulou et al., 2014).

Regarding geographical distribution, the municipalities that present cattle carrying Salmonella make up the western area of the region, connected by federal highways 71 and 207. Here, six of the fourteen studied cattle ranches are located, and is the only land route by which feed and supplies for the livestock feeding are distributed, as well as the products of its exploitation. Therefore, it will be necessary to evaluate if there is any source or mechanism of Salmonella contamination in the bovine feeding sources in this area of the region and in the particular practices of antimicrobial treatment and prophylaxis of veterinary doctors who take care of livestock in the area.

All of the above results because of the process of animal food production, which involves large amounts of antimicrobial agents either for therapy, metaphylactic, prophylaxis of bacterial infections or, in feed, to promote growth (Van Broeckel et al., 2015). Globally, intensive livestock farming has increased food production at a low cost per unit, but perhaps at the unrecognized price of increased antimicrobial resistance (FDA, 2010a).

Linking antimicrobial consumption in animals to drugresistant infections in humans is inherently complex, due to the ecological nature of selection pressure for drug-resistant pathogens, as well as to the existence of indirect routes of transmission through the environment (Roca et al., 2015).

In the United States, the use of antimicrobial for animal feeding is estimated to account for $80 \%$ of the nation's annual antimicrobial consumption (FDA, 2010b). A significant fraction of this, involves antimicrobials that are important for the treatment of common human infections, and for performing medical procedures such as major surgeries, organ transplantation, and chemotherapy (Laxminarayan et al., 2013). Modern animal production practices are associated with the regular use of antimicrobials, potentially increasing selection pressure on bacteria to become resistant (Van Boeckel et al., 2015).

Van Boeckel et al. (2015) report that in 2010, the five countries with the largest shares of global antimicrobial use for animal food production were China (23\%), the United States (13\%), Brazil (9\%), India (3\%), and Germany (3\%). However, by 2030, this ranking is projected to be China (30 $\%)$, the United States (10\%), Brazil (8\%), India (4\%), and Mexico (2\%). With this trend and without particular actions for its containment, the problem of drug multiresistance will increase. In Mexico, particularly in the Sonora, Hidalgo, Jalisco and State of Mexico, studies have shown the presence of multidrug-resistant Salmonella in chicken and beef carcasses and cooked foods (Miranda et al., 2009; Pérez-Montaño et al., 2009; Camacho et al., 2010; Gordillo-Benavente, 2019). It is worth mentioning that all the Salmonella strains isolated from neonatal cattle from the Altos Sur region of the state of Jalisco show multiresistance to drugs, according to the criteria of Miranda et al. (2009). Particularly, the strains show resistance to drugs (AMP, CEP, STX, AN, CTX and CRO) that belong to the chemical groups of greater use in human and veterinary antibiotherapy. In addition, it is striking those two samples of diarrheal feces from the same cattle herd belonged to the same Salmonella Anatum clone. The two samples were recovered from different calves, on different sampling dates (July 2012 and January 2013), which indicates an operating source of contamination in the cattle herd. Likewise, between strain 15A44 (from July 2012) and strain 21 A52 (from January 2013), an increase of resistance to CTX (transition from and intermediate category to a resistant one) was observed, even though the use of CTX is contraindicated in newborn cattle.

Finally, the high demand for aminopenicillins, sulfonamides (with and without dihydrofolate reductase inhibitors), penicillins, first, third and fourth-generation cephalosporins and fluoroquinolones might relate to the multidrug resistance shown by Salmonella strains in diarrheal feces of newborn cattle. Although the awareness campaign offered to veterinary doctors was useful to modify the consumption preferences of veterinary drugs in favor of those recommended by the FDA (FDA, 2010b), we also recommend to raise awareness among farm livestock producers, to limit the spread of multi-resistant strains and the consumption of feed prepared with antibiotics for prophylactic or growth improvement purposes. We recommend reducing the prophylactic use of antimicrobials, eliminating the use of antimicrobial agents as development promoters and making the choice of antimicrobials more efficient, selecting alternatives for exclusive veterinary use.

\section{CONCLUSIONS}

In conclusion, this study is, as far as we know, the first study conducted in neonate bovine in the Jalisco State, Mexico, for detecting multidrug resistant Salmonella. Our findings call for initiatives to preserve antibiotic effectiveness while

Volumen XXIII, Número 3 
ensuring food security in low and middle-income countries, as ours. Information on the occurrence of resistance is crucial at local, regional and international levels to guide policy and detect changes that require a response strategy. In order to fulfil this requirement, we need systems for the continuous monitoring on the changes in the occurrence of resistance.

\section{CONFLICT OF INTEREST:}

Authors declare that they have no conflict of interest.

\section{ACKNOWLEDGMENTS}

We, the authors, would like to thank the livestock producers and managers for their permission to collect, for scientific research purposes, fecal samples from the cattle housed on their farms. We also thank the National Council of Science and Technology of Mexico for the scholarship granted to Joel David Diosdado Rojas.

\section{REFERENCES}

Aarestrup, F.M. 2005. Veterinary drug usage and antimicrobial resistance in bacteria of animal origin. Basic \& clinical pharmacology \& toxicology, 96(4): 271-281.

Aidara-Kane, A., Angulo, F.J., Conly, J.M., Minato, Y., Silbergeld, E.K., McEwen, S.A., \& Collignon, P.J. 2018. World Health Organization (WHO) guidelines on use of medically important antimicrobials in food-producing animals. Antimicrobial Resistance \& Infection Control, 7(1): 7.

Arthur, T.M., Kalchayanand, N., Bosilevac, J.M., Brichta-Harhay, D.M., Shackelford, S.D., Bono, J.L., Wheeler, T.L. \& Koohmaraie, M. 2008. Comparison of effects of antimicrobial interventions on multidrug-resistant Salmonella, susceptible Salmonella, and Escherichia coli 0157: H7. Journal of food protection, 71(11): 2177-2181.

Barkocy-Gallagher, G.A., Arthur, T.M., Rivera-Betancourt, M., Nou, X., Shackelford, S.D., Wheeler, T.L., \& Koohmaraie, M. 2003. Seasonal prevalence of Shiga toxin-producing Escherichia coli, including 0157: H7 and non-O157 serotypes, and Salmonella in commercial beef processing plants. Journal of food protection, 66(11): 1978-1986.

Callaway, T.R., Edrington, T.S., Anderson, R.C., Byrd, J.A. \& Nisbet, D.J. 2008. Gastrointestinal microbial ecology and the safety of our food supply as related to Salmonella. Journal of Animal Science. 86:E163-E172.

Camacho, R.O., Acedo, R.L.E., Moreno, I.G.M., Sánchez, M.R.I., Castillón, C.L.G. \& Navarro, N.M. 2010. Detección de Salmonella resistente a los antibióticos en vísceras de pollo. Biotecnia. XII: 3-11.

CDC, 2009. Centers for Disease Control and Prevention. National Center for Emerging and Zoonotic Infectious Diseases (NCEZID), Division of Foodborne, Waterborne, and Environmental Diseases (DFWED). Available at: https:// www.cdc.gov/salmonella/general/technical.html. Accessed July 2013.

CLSI. 2009. M2-A10. Performance standards for antimicrobial disk susceptibility test. 10th ed. Clinical and Laboratory Standards Institute. (Updated standard available at: www. clsi.org.) Wayne, Pennsylvania. USA.

CLSI. 2010. M100-S20. Performance standards for antimicrobial susceptibility testing. 20th ed. Clinical and Laboratory Standards Institute. Wayne, Pennsylvania. USA. Available at: https://www.techstreet.com/mss/products/ preview/1662926. Accessed March 2013.

COMECARNE. 2017. Consejo Mexicano de la Carne, con datos del INEGI. Compendio estadístico 2017 de la industria cárnica mexicana. Available at: http://comecarne.org/wp-content/ uploads/2018/05/Compendio-Estad\%C3\%ADstico-2017v7-1-sin-elab.pdf. Accessed November 2018.

COMECARNE. 2019. Consejo Mexicano de la Carne, con datos del INEGI. Compendio estadístico 2019 de la industria cárnica mexicana. Available at: https://comecarne.org/wpcontent/uploads/2020/05/Compendio_Estadistico_2019. pdf. Accessed Mayo 2021.

Duggan, S., Jordan, E., Gutierrez, M., Barrett, G., O'Brien, T., Hand, D. \& Egan, J. 2012. Salmonella in meats, water, fruit and vegetables as disclosed from testing undertaken by Food Business Operators in Ireland from 2005 to 2009. Irish veterinary journal, 65(1): 17.

Elder, R.O., Keen, J.E., Siragusa, G.R., Barkocy-Gallagher, G.A., Koohmaraie, M., \& Laegreid, W.W. 2000. Correlation of enterohemorrhagic Escherichia coli 0157 prevalence in feces, hides, and carcasses of beef cattle during processing. Proceedings of the National Academy of Sciences. 97(7): 2999-3003.

Evangelopoulou, G., Kritas, S., Govaris, A., \& Burriel, A.R. 2014. Pork meat as a potential source of Salmonella enterica subsp. arizonae infection in humans. Journal of clinical microbiology, 52(3): 741-744.

FAOSTAT. 2017. FAOSTAT México. Organización de las Naciones Unidas para la Agricultura y la Alimentación. Available at: http://www.fao.org/faostat/en/\#data/CL. Accessed November 2018.

FATUS-USDA. 2020. USDA Foreign Agricultural Trade of the United States. Economic Research Service. U.S. DEPARTMENT OF AGRICULTURE. Available at: https:// www.ers.usda.gov/data-products/foreign-agriculturaltrade-of-the-united-states-fatus/us-agricultural-tradedata-update/ Accessed Mayo 2021.

FDA. (2010a). Food and Drug Administration. Guidance for Industry-Studies to Evaluate the Safety of Residues of Veterinary Drugs in Human Food: General Approach to Establish a Microbiological ADI VICH GL36(R) Available at https://www.fda.gov/downloads/AnimalVeterinary/ GuidanceComplianceEnforcement/Guidanceforlndustry/ UCM124674.pdf. Accessed November, 2018.

FDA. (2010b). Food and Drug Administration. CVM Updates CVM Reports on Antimicrobials Sold or Distributed for FoodProducing Animals (Food Drug Admin, Silver Spring. MD). Available at www.fda.gov/AnimalVeterinary/NewsEvents/ CVMUpdates/ucm236143.htm. Accessed March 2015.

Geimba, M.P., Tondo, E.C., de Oliveira, F.A., Canal, C.W., \& Brandelli, A. 2004. Serological characterization and prevalence of $s p v R$ genes in Salmonella isolated from foods involved in outbreaks in Brazil. Journal of food protection. 67(6): 12291233.

Geornaras, I., Yang, H., Moschonas, G., Nunnelly, M.C., Belk, K.E., Nightingale, K.K., \& Sofos, J.N. 2012. Efficacy of chemical interventions against Escherichia coli 0157: H7 and multidrug-resistant and antibiotic-susceptible Salmonella on inoculated beef trimmings. Journal of food protection. 
75(11): 1960-1967.

Gordillo Benavente, M.A. 2019. Prevalencia de Salmonella spp. en alimentos contaminados y descripción según serotipos; tipos de alimentos y jurisdicciones sanitarias afectadas en Chiapas, durante el periodo 2016-2018 (Doctoral dissertation, Facultad en Ciencias Odontológicas y Salud Pública-Maestría en Ciencias en Salud Pública-UNICACH). México State, México.

Gould, D., Kraa, E., Dalton, C. B., Givney, R., Gregory, J., Stafford, R.J., \& Kirk, M.D. 2004. Foodborne disease outbreaks in Australia, 1995 to 2000 . Communicable diseases intelligence quarterly report: 28(2): 211.

Holschbach, C.L., \& Peek, S.F. 2018. Salmonella in dairy cattle. Veterinary Clinics of North America: Food Animal Practice. 34: 133-154.

Hughes, D., Dailianis, A.E., Hill, L., Curiale, M.S. \& Gangar, V. 2003. Salmonella in foods: new enrichment procedure for TECRA Salmonella visual immunoassay using a single rv(R10) only, TT only, or dual rv(R10) and TT selective enrichment broths (AOAC official method 998.09): collaborative study. J. AOAC Int. 86: 775-790.

IIEG. 2019. Instituto de Información Estadística y Geográfica del Estado de Jalisco. Diagnóstico de la región Altos Sur Agosto 2019. Available at: https://iieg.gob.mx/ns/wp-content/ uploads/2019/12/03-Altos-Sur-Diagn\%C3\%B3stico-1.pdf . Accessed July 2020.

Kauffman, G. 1974. "Kauffman White Scheme. WHO. Pd 172, 1, rev. 1,"Acta Pathologica et Microbiologica Scandinavica Section B-Microbiology. 61: 385.

Laxminarayan, R., Duse, A., Wattal, C., Zaidi, A.K., Wertheim, H.F., Sumpradit, N. \& Greko, C. 2013. Antibiotic resistance-the need for global solutions. The Lancet infectious diseases. 13(12): 1057-1098.

Mathew, A.G., Cissell, R., \& Liamthong, S. 2007. Antibiotic resistance in bacteria associated with food animals: a United States perspective of livestock production. Foodborne pathogens and disease. 4(2): 115-133.

Miranda, J.M., Mondragón, A.C., Martinez, B., Guarddon, M., \& Rodriguez, J.A. 2009. Prevalence and antimicrobial resistance patterns of Salmonella from different raw foods in Mexico. Journal of food protection. 72(5): 966-971.

Narvaez-Bravo, C., Miller, M.F., Jackson, T., Jackson, S., RodasGonzalez, A., Pond, K., \& Brashears, M.M. 2013. Salmonella and Escherichia coli 0157: H7 prevalence in cattle and on carcasses in a vertically integrated feedlot and harvest plant in Mexico. Journal of food protection. 76(5): 786-795.

NARMS. 2010. National Antimicrobial Resistance Monitoring System. Food and Drug Administration. Available at: https://www.fda.gov/media/82822/download. Accessed March 2013.

Pérez-Montano, J.A., Gonzalez-Aguilar, D., Barba, J., PachecoGallardo, C., Campos-Bravo, C. A., Garcia, S., ... \& CabreraDiaz, E. 2012. Frequency and antimicrobial resistance of Salmonella serotypes on beef carcasses at small abattoirs in Jalisco State, Mexico. Journal of food protection. 75(5): 867-873.
Rivera-Betancourt, M., Shackelford, S.D., Arthur, T.M., Westmoreland, K.E., Bellinger, G., Rossman, M., ... \& Koohmaraie, M. 2004. Prevalence of Escherichia coli O157: H7, Listeria monocytogenes, and Salmonella in two geographically distant commercial beef processing plants in the United States. Journal of food protection. 67(2): 295-302.

Roca, I., Akova, M., Baquero, F., Carlet, J., Cavaleri, M., Coenen, S., ... \& Kahlmeter, G. 2015. The global threat of antimicrobial resistance: science for intervention. New microbes and new infections. 6: 22-29.

SADER. 2019. Secretaría de Agricultura y Desarrollo Rural. Producción de carne de bovino en el 2019. Comunicado del 16 de marzo de 2020. Available at: https://www.gob. $\mathrm{mx} /$ agricultura/prensa/la-produccion-de-carne-de-res-enmexico-mantiene-un-crecimiento-anual-sostenible-del-25-agricultura?idiom=es Accessed May 2020.

Secretaría de Salud. 2017. Anuarios Estadísticos de MorbilidadDatos abiertos. Dirección General de Epidemiología - Dirección General Adjunta de Epidemiología. Available at: $\quad$ https://www.gob.mx/salud/documentos/datosabiertos-152127. Accessed November 2018.

UGRJ. 2019. Unión Ganadera Regional de Jalisco. Informe de actividades 2018. Available at: http:// www.ugrj.org.mx/index.php? option $=\mathrm{com}_{-}$ content\&task=view\&id=138\&ltemid=228. Accessed May 2019.

USDA-FSIS. 1996. U.S. Department of Agriculture. Food Safety and Inspection Service. Pathogen reduction; Hazard analysis and critical control point (HACCP) systems; final rule. 9 CFR, Part 304. Available at: http://www.fsis.usda.gov/OPPDE/ rdad/FRPubs/93-016F.pdf. Accessed July 2018.

USDA-FSIS. 2008. U.S. Department of Agriculture. Food Safety and Inspection Service. Isolation and identification of Salmonella from meat, poultry and eggs products. MLG 4.04. Laboratory QA/QC Division, Athens, GA.

USDA. 2019. U.S. Department of Agriculture Mexico livestock and products annual. August 2019. Available at: https:// www.fas.usda.gov/data/mexico-livestock-and-productsannual-6. Accessed July 2020.

Van Boeckel, T.P., Brower, C., Gilbert, M., Grenfell, B.T., Levin, S.A., Robinson, T.P., ... \& Laxminarayan, R. 2015. Global trends in antimicrobial use in food animals. Proceedings of the National Academy of Sciences. 112(18): 5649-5654.

Whichard, J.M., Medalla, F., Hoekstra, R.M., McDERMOTT, P.F., Joyce, K., Chiller, T., ... \& White, D.G. 2010. Evaluation of antimicrobial resistance phenotypes for predicting multidrug-resistant Salmonella recovered from retail meats and humans in the United States. Journal of food protection. 73(3): 445-451.

WHO. 2008. World Health Organization. Antimicrobial resistance from food animals. Information note $2 / 2008$. Antimicrobial resistance. International Food Safety Authorities Network. Available at: http://www.who.int/foodsafety/ fs_management/No_02_Antimicrobial_Mar08_EN.pdf Accessed November 2018. 